\section{P-241膀腃癌に対するCDDP併用放射線療法の臨 床的検討 一膀椫温存例の予後について一}

山口大学 1 ?

吉弘悟1)松本洋明 ${ }^{1)}$ 山口史朗 ${ }^{1)}$ 松田健二(1) 福永康二11 長尾- - - 公1) 原 貴彦 ${ }^{1)}$ 和田 尚 ${ }^{11}$ 内藤克輔1)

【目的】局所浸潤性拉よびT1 - Grade 3の膀脱嵒患者に対してCDDP 併用放射線㙩法を施行し，近接効果お上び予後について臨床的検 討を行った。対象と方法】1994年11月から1999年6月までにCDDP 併用放射線潦法を施行した 48 例を対象とした。年齢は45歳から86 歲 (平均66.9歳)，平均観察期間は23.2力月であった。組織学的異 型度は, G2: 12例, G3:36例, 臨床病期はT 1 以下 $: 5$ 例, T2 $: 22$ 例, T3：18例， T4：3例であった。治療はCDDP 70 $\mathrm{mg}^{2} \mathrm{~m}^{2}$ を静注後, 2日目より Linac 180cGy/dayの9日間照射を1 cycleとして2 3 cycle施 行した【結果】近接効果は48例中41例で評価可能で, CR：11例 (26.8\%)，PR：19例（46.3\%）で奏功率は73.2\%であった。試験開 腹, 非治撚的TUR, 手術拒否の3例を除き, 手術は膀胱全摘: 11 例, 傽脱部分切除：5例, TUR：18例に施行し, 多筒所生検の及が11例 で，45例中17例（38\%）がpCRであった。全摘後pCRの3例を含め て37例 $(82 \%)$ で膀脱温存が可能と思われた。膀肤温存 34 例中 16 例 $(47 \%)$ で再発を認め, 7例 (21\%) にdisease progressionを認め, T3b以上の症例が有意にprogression rateが高かった。【結語】 CDDP 併用放射線療法は低侵襲な膀胱温存療法として有用であるが， T3b以上では治療後進行例があり全摘やadjuvant化学㙩法を考虑す る必要があることが示唆された。

\section{膀胱澏 放射線化学療法}

\section{P-242 骨盤内N+膀脱癌例に対する動注と放射線 併用療法}

\begin{abstract}
東北大学 医学部 泌尿器科1)
仙台赤十字病院 ${ }^{2)}$

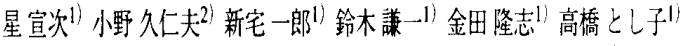

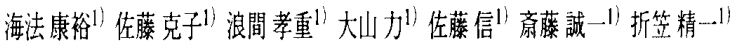

【目的 noeadjuvant療法として化学療法と放射線照射の併用が有效 と見なされている。骨盤内リンパ節のみに転移を認めるN+M0浸 潤性膀胱癌に対しneoadjuvant療法として動注と放射線照射を行っ た25例について検討した。一部の症例には全身化学療法を追加し た。【対象抢よび方法】25例中男性20例、女性5例で年路は44-76才 (平均年齢62才)、移行上皮癌grade2-3が22例、扁平上皮癌2例、小 細胞癌 1 例。リンパ節吸引生検で + と診断したのが17例、リンパ 節郭清で診断したのが5例、画像のみで診断したのがN3の3例。 $\mathrm{N} 1: 6$ 例,N2:15例,N3:4例。動注内容はCDDP50-70mg/body,THP 30mg/body, MTX 30mg/bodyを3-7回行った。放射線照射はLiniacを用 い、全骨盤腔に18-60Gy(平均42Gy.)艺行った。膀胱全摘ないし部分 切除を15例に行い、10例は膀胱の手術を行わなかった。結果】観 察期間は6-173 月で平均48 月。癌死9例、他病死 3 例、他癌死 1 例。5年、10年疾患特異生存率は62\%、51\%で、これまでの報告 の骨盤内リンパ節転移例の5生率、10生率30\%にくらべ20-30\%の 改善をもたらした。しかし、PSが悪く治療を延期せざるを得ず、 早期に転移が進行した症例があった。【結論】骨盤内リンパ節転 移例に対し動注と放射線照射は延命効果がある。
\end{abstract}

漫潤性膀胱掂 リンパ節転移 neoadjuvant療法

\title{
P-243膀胱全摘除術施行症例の盬床的検討
}

\section{P-244 浸閵性膀胱癌に対し膀胱温存をした集学的 治療の検討}

\begin{abstract}
神戸大学 ${ }^{1)}$

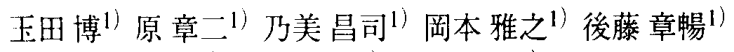
原勲 岡田弘 ${ }^{1}$ 荒川創一1）守殿貞夫 ${ }^{1)}$

【目的】膀胱全摘除術施行症例を、病理学的診断、尿路变更術、 予後に関し検討した。【対象と方法】1978年から1999年まで、当科 にて膀胱全摘除術を施行し、予後を確認し得た118症例（男性；97 例、女性；21例、年齢42才から83才；中央值67才。観察期間は5 246ヶ月；中央值62ヶ月。）を対象とした。【結果】組織型は、移行 上皮癌；109例、扁平上皮癌；6例、腺癌；2例、小細胞癌；1例で あった。悪性度はG1；2例、G2；22例、G3；83例、不明；11例、 深達度は、pTis；11例、pT1；9例、pT2；51例、pT3；28例、pT4； 12例、不明；7例、リンパ節転移は、 $\mathrm{pN} 0 ； 80$ 例、pN1；4例、pN2 ; 12例であった。補助化学療法を施行した症例は16例。尿路変更 の内容は、尿管皮虐瘦；25例、回腸導管；28例、CUR；18例、新 膀胱； 47 例であった。全体での3年及び 5 年の疾患特異的生存率 は65.8\%、55.4\%で、癌死は25例(21.1\%)であった。pT別の3年及び 5 年の疾患特異的生存率はpTis；90.9\%、87.2\%、pT1；89.5\%、 $85.7 \% 、 \mathrm{pT} 2 ; 78.5 \% 、 67.4 \% 、 \mathrm{pT} 3 ; 56.9 \% 、 45.2 \% 、 \mathrm{pT} 4 ; 10.2 \%$ 、 1.3\%であった。またリンパ節転移を認めた16例中、一年以上生存 したのは一例だけであった。
\end{abstract}

膀胱癌 膀胱全摘除術 予後

\section{名古屋市立大学 医学部 泌尿器科 ${ }^{1)}$}

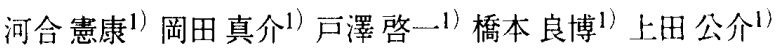
郡 健二郎 1 )

【目的】浸潤性膀胱癌のうち膀胱全摘術の適応を越えて進展した もの、あるいは患者の基礎疾患等の患者背景により膀胱全摘除術 を施行しない症例について膀胱を温存した上での集学的治療を行 つた。その治療成績につき検討を行った。方法】1990年1月から 1999年10月までに膀胱を温存した上での集学的治㙩をした浸潤性 膀胱癌19例を対象とした。年齢は61歳から79歳 (中央値66歳)、吽: 別は男性16例、女性3例であった。組織型は移行上皮癌17例、腺癌 2例であった。異型度はG3が11例、G2が8例であった。StageはT2が 4例,T3が7例、T4が8例であった。治療法は(1)全身化学療法は4例、 (2)全身化学療法+放射線療法4例、放射線療法単独5例、(3)動注化 学療法3例、(4)動注化学療法+放射線療法3例であった。【結果】(1) 全身化学療法4例中CR0例、PR1例、NC2例、PDI例(2)全身化学療 法+放射線療法4例中CR0例、PR2例、NCl例,PD1例(3)動注化学療 法3例中CR0例、PR1例、 $\mathrm{NCl}$ 例,PD1例(4)動注化学療法+放射線療 法3例中CR0例、PR2例、 $\mathrm{NC1}$ 例,PDO例であった。【総括】放射線療 法に全身化学療法または動注化学療法を併朋する治療法はQOL I: 有用であると考えられた。

\section{漫潤性膀胱瘦 膀胼温存 集学的治療}

